\title{
DOES COMPETITION ENFORCEMENT PREVENT COMPETITIVE STRATEGIES OF DIGITAL PLATFORMS: EVIDENCE FROM BRICS
}

\section{S. B. AVDASHEVA}

Faculty of Economic Sciences, National Research University Higher School of Economics, Russia ${ }^{\text {a }}$

\section{V. KORNEEVA}

Faculty of Economics, National Research University Higher School of Economics, Russia ${ }^{\mathrm{b}}$

\begin{abstract}
Competitive strategies of platforms often involve contractual arrangements that might be considered as anticompetitive. Since recent decisions of European Commission after investigations against Google in 2017 and 2018, and Bundeskartellamt against Facebook in 2019, the standards of liability for abuses applied by competition authorities will influence business models of digital platforms. This paper summarizes theories of harm applied by BRICS competition authorities applied towards multi-sided platforms under investigations. One may expect that BRICS approach to be harsher compared to mature competition jurisdictions. However, a comparison shows that discrimination and tying with exclusionary effects have been the focus of investigations and decisions in BRICS. Remedies in the infringement decisions are intended to protect rivalry through "no restriction of multihoming" conditions. There is no evidence that BRICS authorities apply a specific economic theory of multi-sided platforms. At the same time, BRICS competition enforcement could be applied as one of the legal instruments when one platform tries to crowd out another from global markets.
\end{abstract}

Keywords: multi-sided platform, competition policy, enforcement, theory of harm, BRICS.

JEL: L40, L41, L42, K21, L14.

This article is an output of a research project implemented as part of the Basic Research Program at the National Research University Higher School of Economics (HSE).

Postal Addresses: ${ }^{a}$ Higher School of Economics, 11 Pokrovsky Blvd, Moscow, 101000, Russia; ${ }^{b}$ Higher School of Economics, Faculty of Economics, 25/12 B. Pecherskaya St., Nizhny Novgorod, 603155, Russia. (c) S. B. Avdasheva, D. V. Korneeva, 2019 


\section{INTRODUCTION}

Digitalization has transformed many industries during the last decades. A growing number of companies operate as open ecosystems that link users, extend across sectors and harness network effects. In 2019, seven out of the world's 10 largest corporations derive much of their value from multisided platforms. Top-3 largest companies in this list are Apple, Microsoft and Amazon with market value of about a trillion U.S. dollars each [Statista, 2019a]. Network effects enable a rapid business growth. Many digital platform firms exceed comparable traditional firms by market capitalization, while the numbers of employees is much lower. For example, BMW was founded in 1916 and as of 2018, its market capitalization reached USD 51 bln. while the number of employees was 131 thousands. At the same time, Uber began its activities only in 2009. Nevertheless, as of 2018 its market capitalization is even higher (USD 76 bln.) and the number of staff is much lower (16 thousands) as of 2018 [Jacobides, Sundararajan, Van Alstyne, 2019].

Despite platforms are rather an old business model, it has been updated to the preferences of the participants in digital economy. Users prefer crowdsourcing and ask only for the best possible match for their needs for instead of looking for a particular seller.

At the same time, many antitrust decisions and investigations of multi-sided platforms have emerged. To illustrate the scale of potential harm created by multi-sided platforms we refer to the most high profile antitrust cases against MSPs which were undertaken by BRICS competition authorities. It is not surprisingly that these are primarily cases against the world's largest digital companies. The European Commission has imposed three massive fines on Google as result of a wide-ranging antitrust investigations. In 2017, Google was fined $€ 2.4$ bln. for abusing its market dominance as a search engine by giving an advantage to its own comparison shopping service [European Commission, 2017b]. The next year it was penalized even to a higher extent: a record $€ 4.34$ bln. fine for abusing its dominant position of its Android operating system in order to extend the coverage of Google's search engine [European Commission, 2018]. A third fine appeared in March 2019, when European Commission fined Google with a $€ 1.49 \mathrm{bln}$. for blocking online advertising rivals [European Commission, 2019]. These fines have been calculated on the basis of the value of Google's revenue from the relevant operations in the countries concerned. Nevertheless, even a comparison with Google's revenue worldwide (USD 136 bln. in 2018, USD 110 bln. in 2017, USD 90 bln. in 2016 [Statista, 2019b]) indicates a huge scale of these fines.

Next important step in antitrust enforcement against digital platforms was investigation and decision of German competition authority Bundeskartellamt on the abuse of dominance by [Bundeskartellamt, 2019]. There are important features of this decision. First, mature competition jurisdiction establishes for the first time exploitativetype abuse of dominance, that is an abuse where losses of consumer surplus but not restriction of competition is an evidence of competition rule violations. Second, competition authority stresses that exploitative abuses are possible in zero-pricing markets, where users obtain service "for free".

Not only Google has been an object of antitrust investigations recently. In July 2019, The U.S. Department of Justice announced a huge investigation into the Big Four Tech companies (Google, Facebook, Apple and Amazon), suspecting an engagement in practices that have reduced competition, limited innovation and harmed consumers [Kelly, 2019]. In another case, The Federal Trade Commission has approved fining Facebook for USD 5 bln. to settle an investigation into the company's repeated privacy violations following the Cambridge Analytica revelations [The Guardian, 2019]. This fine would be the largest ever imposed 
by the FTC against a technology company, since the company had more than USD $15 \mathrm{bln}$. in revenue in the first three months of 2019 [The Guardian, 2019].

Interpretation of MSP's conduct by competition authorities is important. A platform strategy is based on positive crossplatform network effects, which allow participants to benefit from the presence of others in contrast to a traditional competitive strategy, when customers determine their willingness to pay independently. Strategies of MSPs may become targets of antitrust enforcement both because of the size of platforms and because their strategies may seem suspicious in the context of competition legislation. According to [Van Alstyne et al., 2016, p.55], "the focus of strategy shifts from controlling to orchestrating resources, from optimizing internal processes to facilitating external interactions, and from increasing customer value to maximizing ecosystem value". In terms of competition rules, orchestrating resources sufficient to provide network effect (in order to maximize ecosystem value) means dominance. Orchestrating resources may imply restrictions on the use of competing platform (single-homing), and prevention of upgrading of users. Finally, a platform combines value creation for ecosystem with value extraction from ecosystem, and the latter may be considered under some circumstances as exploitative abuse of dominance.

The development of business strategies in MSPs in the future will be limited by the standards that competition authorities will implement. This raises an important question whether the techniques traditionally used to define markets, to assess market power and efficiencies, remain adequate for these purposes in the MSPs markets. For international digital platforms, standards that BRICS competition authorities apply are important as they limit boundaries of business strategies of digital platforms in the markets attractive because of large population.
Another important aspect is the similarity or difference in approaches of antitrust authorities across countries, which is extremely relevant for global companies that are trying to maintain their presence in different markets. The position of the BRICS countries is especially of interest because: (1) they started investigations earlier; (2) they are traditionally reproached for excessive rigidity [Giannaccari, Van den Bergh, 2017]. In the article, we, first, compare approaches of BRICS competition authorities towards multi-sided digital platforms with those of EU approach, and, second, approaches of the authorities in different BRICS countries.

The purpose of this paper is to analyze the theory of harm (explanation how and why specific conducts restrict competition and/or harm consumers) that BRICS competition authorities apply in cases involving MSPs and determine how antitrust decisions restrict business models of MSPs in order to identify whether competition enforcement in BRICS may pose a serious threat to the development of business strategies of MSPs in BRICS markets. In our analysis, we consider both transaction platforms (platforms that connect users to make a transaction) and non-transaction platforms (platforms in which different types of users do not interact directly). For competition concerns, we consider concerns on competition of platforms (that implies the right of a user to switch between platforms) and concerns on competition on platform (that requires the right of a user to access the resources accumulated by a platform).

The goal of section 1 is to describe and explain the approaches that BRICS competition authorities have taken so far towards MSPs. In section 2, we briefly recall the theory of entry and exclusion under network effects. Section 3 summarizes implications from competition law and the economics of MSPs for enforcement, taking into account specific BRICS conditions. Section 4 reviews theories of harm/competition concerns that BRICS authorities 
elaborate under enforcement, respective remedies and other instruments of competition policy. Section 5 concludes.

\section{MULTI-SIDED PLATFORMS: INCREASING ATTENTION OF COMPETITION POLICY}

Multi-sided platforms (MSPs) are among the hot topics for managerial [Eisenmann, Parker, Van Alstyne, 2006] and economic [Rochet, Tirole, 2006] studies during at least the last two decades. Despite the fact that network externalities, both direct and indirect (or cross-platform) ${ }^{1}$, emerged and were studied in the pre-digital era, the importance of the issue in the digital era sharply increased. The reason is the increasing opportunities for MSPs to exploit crossplatform network externalities and obtain large profits in digital markets. Moreover, networks can form much faster than before.

In recent years, there has been a prominent increase in the platform economy. In its "Technology Vision 2016" report, the global consulting firm Accenture argues that "unparalleled growth of the digital economy has put it on course to account for $25 \%$ of the world's entire economy by 2020 , up from $15 \%$ in 2005. Platform business models represent a fast-increasing proportion of the overall total" [Walles, 2018].

Platform-based companies both create new markets and transform existing downstream markets. Big data represents a particular resource of platforms since it attracts the large number of customers. Processing of big data allows platforms to improve its own decision-making (e.g. to develop a price discrimination scheme) or to improve ser-

1 In the literature, two types of cross-platform effects are discussed. The direct network effect appears when user's benefit from a platform is directly affected by the number of users [Katz, Shapiro, 1985]. The indirect network effect means that users on one side of a platform benefit from an increase of the number of users on the other side of a platform [Armstrong, 2006]. vices for customers (e.g. targeted advertising). Big data may result in a more efficient management of resources that could provide annual net savings of up to $€ 600 \mathrm{bln}$. for EU enterprises. Digital platforms may capture $30-40 \%$ of the value created in the industrial chain ${ }^{2}$.

However, along with the enhanced resource efficiency, the large size of MSPs may cause a strong impact on competition in platform and downstream markets ${ }^{3}$. In their value chains, large MSPs act as dominant players ("lead" firms in the sense used by the theory of global value chain) [Gereffi, Humphrey, Sturgeon, 2005]. Governance in value chains represents not only rule-setting and enforcement but also reallocation of value created in the value chain in favor of the dominant participant. The share of value distributed towards independent participants in downstream markets may decrease. This suggests that competition ana-

2 The forecast [European Commission, 2016] uses as an assumption that most European companies use digital resources at the level that their competitors on the digital frontier already use. Increasing the share of value added comprises new transactions generated by the platforms, replacement of the less efficient instruments of advertising, planning, logistics by more efficient ones, and the development of new products and services that would be available by digitalization (for instance, within the area of the Internet of Things).

3 The extensive literature on the impact of MSPs on downstream markets does not fully support expectations of anticompetitive influence on downstream markets. On the one hand, previous studies [Schmalensee, 1981; Whinston, 1990] have examined entry in complementary markets, but without focusing particularly on platform dynamics or cross-platform effects. These authors suggest that monopolists have several strong incentives for entering complementary markets to offer bundling or tying. On the other hand, other papers [Farrell, Katz, 2000; Becchetti, Paganetto, 2001] show that if a monopolist cannot duplicate the entrants' innovations at a reasonable cost, then it may have strong incentives to try to state to entrants that it will not enter the market for complements to stimulate the competitive efforts of independent suppliers of the complementary product. 
lysis should look beyond the effects of horizontal competition on consumers or total welfare towards to include the influence of value chain design on the generation and distribution of value [Lianos, 2017]. In the latter dimension, one important issue is vertical competition as an ability of the participants in the chain to upgrade and receive a fair part of the overall amount of value generated.

In many dimensions, conditions for successful business models in MSPs are different from related conditions in markets where network externalities are weak. The same is true for conditions that profit-maximizing decisions should satisfy. As a result, standards to identify anticompetitive conduct that competition authorities traditionally apply to one-sided markets (occasionally with important reservations) could be inapplicable for MSPs.

Recall the example of below-cost pricing. We already know that "horizontal" dynamic economies of scale can lead to non-predatory below-cost pricing. However, with MSPs, there is an additional issue: network effects between different sides of the platform ("across the platform") so that one can get below cost pricing on the sides where demand is more elastic. Such below cost prices do not reflect a predatory intent but they can have a predatory effect on firms which are not as "vertically" integrated as MSPs.

MSPs have the ability to unilaterally influence downstream markets, including pricing, product differentiation, and entry conditions. The influence of MSPs on horizontal and adjacent markets might also be anticompetitive. Antitrust enforcers worldwide focus closely on large MSPs, from Microsoft to Google [Evans, Noel, 2008; Haucap, Stühmeier, 2015]. However, in all these cases, the competitive analysis of MSP conduct $^{4}$ can be tricky, for two main reasons.

4 The best-known example is a dispute between different interpretations of Microsoft conduct when crowding Netscape out of the market for web-
Firstly, even if some conduct reduces horizontal competition in a given market, crossplatform effects can generate compensating benefits in another market. Secondly, dynamic efficiency, which is central to many MSPs' business model further complicate the task [Katz, Shelanski, 2005]. Therefore, a necessary step of the analysis is to weigh losses from competition restrictions against welfare gains. This is especially important under the analysis of economic concentrations.

Competition authorities in BRICS countries face the same problems when investigating and deciding on the conduct of MSPs as their colleagues do in more developed jurisdictions. In recent years, they have made important decisions on abusive conduct of MSPs and on remedies required for the approval of economic concentrations. The decisions of BRICS competition authorities have less extensively analyzed than their counterparts in the EU or the US. This is especially unfortunate as BRICS policy towards digital MSPs might substantially diverge from that in the USA and Europe.

Important differences indeed arise because of BRICS' desire to catch-up with more advanced economies. In most BRICS countries, initial steps in the development of domestic digital markets were made by global rather than domestic platforms. At the same time, countries explicitly stress the strategic objective to develop national digital innovation systems ${ }^{5}$ involving domestic suppliers of digital solutions, including applications and business models.

The influence of market demand in BRICS on the potential competition in digital value chains, governed by MSPs, is contradictory. On the one hand, large market volume in many cases allows for interplatform competition, even if a platform exhibits substantial

browsers [Gilbert, Katz, 2001; Klein, 2001; Whinston, 2001]. In the discussion, many arguments were developed in the "one-sided market" logic but at least taking into account direct network externalities.

${ }^{5}$ See detailed description in the introduction. 
increasing returns to scale ${ }^{6}$. At the same time, large market volume makes a domestic market attractive for global platforms, which then tend to dominate the local market. Therefore, domestic competition authorities may give special attention to the threat of foreclosure for domestic competitors and other forms of softening competition in favor of global MSPs, assigning higher weight to the gains of domestic competitors in developing theories of harm. In contrast, they may not take into account decreasing incentives of global companies to innovate as a negative externality of competition enforcement since the impact of their decisions on the investment policies of large global firms is likely to be minimal. Given this difference of perspective as well as the fact that mature jurisdictions have not elaborated an unanimous approach to competition policy, the BRICS need to develop their own approach towards MSPs.

\section{IMPLICATIONS OF THE ECONOMIC THEORY OF MULTI-SIDED PLATFORMS FOR COMPETITION POLICY}

\subsection{Incentives to Enter and Market Structure of MSP}

Competition policy addresses markets where demand and supply conditions make imperfect competition sustainable. A difficult task in these markets is to distinguish between market power that is explained by demand and supply and the conduct of

${ }^{6}$ UnionPay payment system is a successful newcomer in the payment system markets with large cross-platform effects due to large scale; Russian MIR ("World") is trying to achieve the same. In the Chinese market, there is intense competition between Alibaba and Tencent in many markets connected by relevant MPSs. In the Moscow market of taxi aggregator services, there has recently been sharp competition between Yandex-Uber, Sitimobil (domestic company) and Gett, with substantial changes in market shares annually. dominant companies that enhance market power.

In the presence of MSPs, this is especially difficult, as the economic theory of entry in the market with network effects shows. This theory for a one-sided market followed several important stages. The starting point was that under high entry costs, entry deterrence could be achievable and profitable [Bain, 1956]: by choosing a price at which the entrant could not expect to cover the costs of entry, the incumbent could remain a monopolist. Anyway, it was criticized for the assumption (called the SylosLabini postulate [Sylos-Labini, 1957]) that a potential entrant considers price (or quantity) set by the incumbent before entry as being unchanged after entry. If this assumption is not true, then pre-entry price (quantity) cannot predict the profit that a new entrant obtains in case of entry ${ }^{7}$.

However, these conclusions no longer hold in markets with network effects. Consider ${ }^{8}$ a market for a network good with two sellers - incumbent $(I)$ with the installed base (measured by the number of users $N$ ) and entrant $(E)$ with zero installed base. The unit cost of entrant is lower than that of incumbent $c_{E}<c_{I}$, and the entry cost of incumbent is zero.

Consider highly dispersed users with unit demand and willingness to pay, $P_{i}=f(N)$, $\frac{\partial f}{\partial N}>0 ; f(N=1)=0 ; \lim _{N \rightarrow \infty} \frac{\partial f}{\partial N}=0$. There are

$N$ old users who constitute the installed base of an incumbent, and they do not need to pay again for the good in a new period. Now, $N$ new users enter the market. Assume that the entrant has unit $\operatorname{costs} c_{E}$ which are

7 Historically, this point was raised by Dixit [Dixit, 1980] in the dispute with Spence [Spence, $1977]$.

8 The example presented further is based on [Karlinger, Motta, 2012]. In the model, there is only one network good sold by an incumbent, and that good potentially could be sold by an entrant. However, for the overall logic, only network externalities matter for the conclusion. 
lower than the unit costs $c_{I}$ of the incumbent. Further assume that if the incumbent is unable to discriminate between old and new users, there are two pure-strategy Nashequilibria. One is an entry equilibrium where the entrant sells at price $P=c_{I}-\varepsilon$, incumbent sets price equal to unit cost, and all users buy from the entrant. Another is an exclusionary equilibrium when incumbent sells at price $P=f(2 N)$, entrant sets any price lower than incumbent, but all users buy from the incumbent. It follows that entry by a more efficient firm might be deterred even with zero entry cost and even though the incumbent charges the highest possible price. A customer does not gain from switching to a lower-price alternative if the positive network effect is sufficiently large. Indeed, if the available network for entrant is small $\left(F(2 N)-F(N)>c_{I}\right)$, no cost advantage would be sufficient for successful entry.

An incumbent with a large enough installed base does not need to sacrifice any margin to prevent the entry of a potential competitor. The model explains why size itself may prevent entry and may weaken competition, even without any intention or special actions from the incumbent ${ }^{9}$. A monopoly structure of markets with large network externalities may result from the crossplatform effect itself.

This model has several implications for competition policy. The network effect is sufficient to explain the persistence of imperfect competition. Additional factors of cost and service advantages of a platform, including cost subadditivity, informational advantages because of data collected, or superior prediction abilities, are not necessary to explain high concentration. This basic difference should be taken into account by competition enforcement, possibly justifying a specific approach.

\footnotetext{
9 The important part of the model is the explanation of the impact of different degrees of price discrimination on the availability of exclusionary/ entry equilibrium. The authors show that under third- and second-degree price discrimination, only an exclusionary equilibrium is sustainable.
}

\subsection{Impact of Network Externalities on the Effectiveness of Exclusionary Contracts}

For many platform businesses, participants on either side can choose between single- or multi-homing. Single-homing might be economically justified without any special contract terms or might result from contract clauses proposed by MSPs, explicitly requiring single-homing or making it de facto preferable by providing steep quantity or loyalty discounts. In the latter case, the effects of single-homing should be analyzed through the lens of the theory of vertical restraints.

Historically, the so-called Chicago school provided important challenges to all the theories of exclusionary conduct under rational decisions of users and incumbents. A conventional presentation of the Chicago paradox [Rasmusen, Ramseyer, Wiley, 1991] is that if after entry an incumbent and an entrant with identical unit costs compete a la Bertrand (with equilibrium prices therefore equal to margin-al costs), any exclusionary contract under a price higher than marginal cost cannot be supported in a Nash equilibrium. There is a wide range of postChicago models of vertical restraints, which identify conditions that make equilibrium with exclusionary contracts possible. The models include incomplete information on the cost function of a potential entrant [Aghion, Bolton, 1987], imperfect competition after entry and specifically important for MSPs - miscoordination between users [Rasmusen, Ramseyer, Wiley, 1991].

The incentives and ability of MSPs to impose exclusivity clauses is greater than for single-sided businesses [Amelio, Karlinger, Valletti, 2018]. Firstly, when a platform binds the users on one side (call it side A) with an exclusionary agreement, positive cross-platform (indirect) network externalities increase demand and willingness to pay on another side (call it side B). This makes it easier to compensate users on side $\mathrm{A}$ to prevent their profitable deviation from the 
exclusionary contract. As Armstrong and Wright stress [Armstrong, Wright, 2007], exclusivity in this case substantially affects the distribution of surplus across subgroups of users on either side because, under multihoming, MSPs compete for the users who are multi-homers, extracting the surplus from those who are single-homers. Competition forces lower prices for multi-homers (as their demand becomes more elastic due to the Rochet-Tirole condition), but higher prices for single-homers.

Several remarks are important here. First, the redistribution of surplus between different sides of platform does not provide clear-cut criteria to identify a competitionweakening effect as the pattern is similar to the rule for pure short-term profit maximization is similar - increase the pricecost margin for the side with low demand elasticity and "subsidize" the side with high elasticity of demand. Second, exclusivity, or single-homing, is not necessarily welfaredecreasing. It might be welfare-enhancing (and competition-preserving) when several competing platforms apply single-homing [Calzolari, Denicolò, 2013]. This is because the platforms' incentives to compete intensely to attract single-homers are high. Third, multi-homing vs single-homing affects the welfare effects of other business practices.

\subsection{Justifications of Exclusionary Conduct}

The origin of the positive cross-platform effect is important to develop an efficiency defense for seemingly anticompetitive conduct. Theory and empirical evidence [Calzolari, Denicolò, 2013; Lee, 2013] support pro-competitive justification for vertical restraints resulting in exclusivity when the sector is sufficiently competitive. To be competitive, a smaller platform might use vertical restraints to achieve critical mass and "get the ball rolling". In contrast, the efficiency defense for vertical restraints or similar policies of a dominant platform should address the origin of cross-platform effects. For transaction platforms, such as hotel booking platforms for example, the exclusivity clause might be the cheapest means of avoiding free-riding, in which parties use the information and contacts available through one platform before completing the transaction either on another platform or by contacting the other side directly.

For digital platforms, additional justifications arise because of the Schumpeterian nature of competition in the sector. In digital markets, competition often takes the form of envelopment [Eisenmann, Parker, Van Alstyne, 2011], also known as drastic innovation, in which a new technology completely crowds out the previous one. In such cases, the meaningful competition is for the market rather than in the market.

\section{UNRESOLVED AND PROBLEMATIC ISSUES IN COMPETITION POLICY TOWARDS MULTI-SIDED PLATFORMS}

A brief survey of economic models highlights several groups of implications for competition policy, including content of analysis, analytical tools and policy instruments. We begin with the first group - type of analysis that competition authorities should undertake. Firstly, the effects of a particular conduct by a MSP depend on market structure and share on all sides of the platform. Moreover, the same conduct (e.g., singlehoming) may be pro-competitive for smaller platforms but anticompetitive for the dominant one. Therefore an effect-based approach should be applied towards digital MSPs [Katsoulacos, Avdasheva, Golovanova, 2016].

Secondly, it is difficult to distinguish between the deterrent effect of cross-platform network externalities and the effects of exclusionary conditions in MSPs' contracts. If the latter takes place, it can have significant welfare losses, both static (higher price level) and dynamic (worsening entry 
conditions and therefore a decrease of incentives to innovate by entrant).

Finally, in the competition jurisdictions where legislation addresses not only exclusionary but also exploitative abuses, sustainable dominance of an MSP makes exploitation of users possible. In terms of value chain theory (VCT), MSPs dominate over their respective value chains [Boudreau, Hagiu, 2009], elaborating and enforcing rules of transactions between users on different sides of platforms.

Performing important tasks within the value chain, an MSP might be interested in redistribution of the value created within the chain and even in preventing the upgrading of value chain participants [Gawer, 2011; Gawer, Cusumano, 2014; Muzellec, Ronteau, Lambkin, 2015]. There is not always a clear borderline between efficient value chain governance and what competition law calls exploitative abuses. This specific nature of the MSPs' position towards value chain allows for many theories of harm.

A second group of implications concerns the analytical tools available to the competition authorities. The bad news is the low discriminatory power of the tests, which authorities usually apply to "normal" markets. If applied mindlessly to MSPs, these tests would result in either a high probability of wrongful convictions (Type I errors) or wrongful acquittals (Type II errors).

As we have mentioned above, below-cost pricing on one side of a platform cannot indicate predatory intent. Correspondingly, cost-based tests on for excessive pricing on one side of a platform also lose discriminatory power, as a high price on one side of the platform might be the necessary compensation for low or even negative prices on another side [Katsoulacos, Jenny, 2018]. The same can be true for other types of exploitative conduct. Taking into account the fact that profit-maximizing vector of prices for the clients of platforms implies a kind of "cross-subsidization", any benchmarking analysis is extremely difficult, if possible.
Other traditional competition policy instruments and techniques might also be more difficult to apply. For example, the notion of "profit sacrifice" or "no economic sense" tests cannot be applied to a single side of the MSP or even to a limited subset of the sides in which the MSPs are involved. Applying the test to a single side would risk concluding that there is a profit sacrifice even though the lower margins on that side help to generate higher margins on another side, without any profit sacrifice overall. An "equally efficient test" for any exclusionary agreements is also difficult to apply for MSPs. Since the main source of efficiency is size as a driver of network externalities, an "equally efficient" competitor should be a competitor of equal size of network. Even a mental experiment of that kind is extremely difficult to conduct as network benefits can be hard to value. The dynamic nature of platform markets add to the difficulties faced by competition authorities. On the one hand, large share does not guarantee automatically equate dominance in terms of an ability to influence the market unilaterally ${ }^{10}$. On the other hand, if vertical restraints prevent entry, this situation may induce substantial welfare losses in dynamic markets. In particular, with potential drastic innovation, dominance might be short-lived. However, the main MSPs have been there for quite a few years now. The possibility of drastic innovation does not imply lack of dominance in terms of unilateral static effect. It only does if the probability of drastic innovation itself increases when the MSP follow a particular conduct (say raise prices).

For exploitative abuses, additional complications arise when the competition authority selects a benchmark for comparison. One of the implications of VCT is that a dominant MSP may impose 'unfair' contract

10 There are many examples in platform businesses in which a seemingly dominant company was crowded out of the market due to drastic technological innovation [Eisenmann, Parker, Van Alstyne, 2011]. 
terms. However, standards of fairness are very difficult to follow anyway ${ }^{11}$. Difference between MSP and traditional business model brings additional complications. Straightforward comparisons might be misleading. Taxi drivers under an MSP business model obtain substantially lower earnings per hour than do comparable taxi drivers in traditional taxi companies. Uber, Gett or Yandex Taxi for instance internalize transaction costs for both types of users - passengers and taxi drivers. In this respect, taxi services provided by an MSP differ from those provided by independent drivers. The same is true for drivers. As a result, comparison between per hour earnings would be possible only by taking transaction costs into account, which is extremely difficult. Return on capital would also be compared with great caution: under MSP business model risk both of aggregators and taxi drivers differs with the risk level of traditional taxi services, to be compared with. These complications are not particularly specific to MSP, but they require sophisticated comparison of risks, returns, prices etc.

Unfortunately, the difficulty in supporting a theory of harm for MSPs does not mean that particular MSPs never adopt anticompetitive conduct, as the efficiency explanation of large size suggests. On the contrary, MSPs from Microsoft to Google have extensive records of exclusionary conduct [Baseman, Warren-Boulton, Woroch, 1995; Economides, 2001; Lévêque, 2005; Akman, 2018; Amelio, Karlinger, Valletti, 2018].

Sufficient evidence on the absence of anticompetitive conduct of an MSP on interplatform competition is an absence of any restrictions on multi-homing, naked or constructive. However, regardless of the business practice of the MSP, such evidence is valid only in cases where multi-homing is technically available, economically reason-

11 See, for instance, on the issue of fairness under European enforcement against excessive pricing [Jenny, 2018]. able and is not hampered by behavioral biases on the part of users if multi-homing is possible, it also prevents exploitative abuses. If several taxi aggregator services compete, they compete not only for final customers but also for drivers. The probability of keeping drivers' compensation at a fair level increases under competition.

A third group of implications addresses the appropriate instruments of competition policy towards MSPs. If competition law and economics cannot provide a reliable set of tests to distinguish between lawful and unlawful conduct, the two remaining extreme options are nonintervention and sector-specific regulation. Sector-specific regulation for MSPs may emerge outside competition policy. For instance, there was a recent discussion on data as an essential facility that platforms obtain [Graef, 2016; Graef, Wahyuningtyas, Valcke, 2015], with strong arguments both pro and con [Tucker, 2019]. International experience shows that the issues of market power over data might be addressed in different ways, including FRAND rules, widely applicable in the EU [Heim, Nikolic, 2019], or by establishing explicit property rights on personal data, which would allow data portability [Takigawa, 2018].

Advantages of the alternative solutions are that they do not rely on the premise that the assets of an MSP are essential facilities or that an MSP is a natural monopoly. In turn, this premise is not always easy to support. The boundary between "natural monopoly" and "contestable market of one seller" is a threat of new entry or envelopment. In some MSP markets, threat of new entry emerges because of quite similar use of applications. For instance, taxi aggregators and aggregators of food delivery work in similar way. In many markets that platforms use geolocations, entry on other market is possible and does not require high fixed costs. Envelopment may emerge in similar way, by developing of a particular digital decision for another purposes. Unfortunately, the probability of envelopment

PЖM 17 (4): 547-568 (2019) 
often can be observed only ex-post but not ex-ante.

Limitations of the sector-specific regulation option follow from the dynamic and innovative nature of digital platforms. Many business practices still lack consistent assessment in terms of their impact on competition. Regulatory rules being fairly elaborated in procedural terms may not achieve desired objectives, but they can easily provide unexpected spillovers. One intermediate option for competition authority is to develop a code of fair business practice ${ }^{12}$. A code of fair conduct permits engaging a targeted protection group in the elaboration of rules and then combining a broad description of principles with industry expertise in conflict resolution.

\section{COMPETITION POLICY TOWARDS MULTI-SIDED MARKETS IN BRICS}

In this section, we summarize the records of competition enforcement in BRICS countries. BRICS group consists of countries with relatively young competition jurisdictions. Recent laws in force were adopted from 1999 in South Africa to 2011 in Brazil. Countries follow different paths of the development of competition in digital markets, from China, were after "Great Firewall" domestic platforms flourish within and beyond national borders, to Brazil that is open towards international platforms. Until recently, countries from BRICS group, excluding China, accumulated experience of competition enforcement towards digital platforms. In the investigations of many conducts of MSPs, including Google Shopping and

12 In Russia, codes of fair conduct are developed in many industries where there are concerns, first, about exploitative conduct of dominant companies. At the time of submission of this article, a code of fair practice for supplier-retailer contracting, a code of conduct for auto-makers and their dealers, and a code of fair practice in the pharmaceutical industry are in force.
Google Android cases, decisions of BRICS authorities preceded similar decisions of European Commission.

\subsection{Market Definition and Multi-sided Markets}

BRICS competition authorities usually apply different approaches to transaction vs nontransaction platforms. For transactions platforms (occasionally called aggregators see, for instance, the decision on the UberYandex merger ${ }^{13}$, the affected markets are defined as platform services. However, the digital nature of a platform does not always serve as a feature that defines the market. For instance, in Uber-Yandex mergers [FAS Russia, 2019], the Russian FAS considers "traditional aggregating taxi services" to be a substitute for a mobile platform that belongs to the same markets.

The Brazilian CADE follows the same path in the assessment of the competitive effect of Uber's entry into Brazilian municipal markets. Independent taxi services are considered competitors in the same markets, affected by Uber's entry. In both the Russian and Brazilian cases, a transaction between users defines the market.

In the case of non-transaction platforms (e.g. Facebook, Google), authorities generally consider several distinct markets, interrelated within the platform. For instance,

${ }^{13}$ Concept of aggregators vs platforms are widely explored in strategic management. A distinction is that participants in the value chain of aggregators do not contribute to the value that the aggregator provides. In contrast, a "genuine platform" in its business benefits from the value created by the users. Therefore, for the aggregators, in contrast to platforms, there are no special incentives to invest in development of the users. Without disputing this distinction, even "pure aggregators" such as online taxi services assist their users in promoting competitiveness. From the perspectives of competition law and economics, the distinction between aggregators and platforms seems to be not very important, even if is important for strategic management. In both cases, network effects explain market structure and efficiencies in the market. 
in the case of distorted search results, the Competition Commission of India defines two markets: Online General Web Search in India and Web Search Advertising Services in India [Competition Commission of India, 2012]. Considering the alleged restrictions on multi-homing in sponsored search market, CADE also does not include the other side of the platform in the market [CADE, 2013]. In the Android case, the Russian FAS considered that Google was dominant in the markets for Operating Systems market, in the Application Store market [FAS Russia, 2015], and the affected adjacent markets pre-installation of applications, products, services, where OEMs are buyers and application developers are sellers ${ }^{14}$.

\subsection{Theories of Harm}

\subsubsection{Exclusionary conduct through vertical foreclosure}

Vertical foreclosure is at the center of the theories of harm in the investigations of MSPs. Some business practices might be considered naked exclusion of competing services [Google Android Russia, 2015] or foreclosure through the limitation on contract terms to other potential counterparties through price-parity conditions.

\subsubsection{Exclusionary conduct through other forms of competition softening}

Discrimination is another means of competition softening involving MSPs (see [Com petition Commission of India, 2012]). Discrimination in terms of access to customers' attention, "clicks" and traffic substantially affects the competitiveness of products. To our knowledge, no decision of a BRICS competition authority contains a quantitative

14 Under appeal of the FAS decision, Google tries to challenge market definition by defining market more broadly as the market for software. An attempt to define the market in this way was rejected by a commercial court. The judge mentions, among other points, that this type of market definition does not allow identifying the source of market power and disguises abuses of dominance. assessment of the impact of search distortion on the comparable competitiveness of suppliers towards final customers similar to the analysis performed by the Directorate General of the European Commission [European Commission, 2017a]. However, the underlying logic of the decision is essentially the same. Standard of legal conduct in this case is "net neutrality"; a search engine is considered an essential facility that should bear specific responsibility to provide fair contract terms to competitors ${ }^{15}$.

\subsubsection{Exploitative conduct in a value chain perspective}

No competition authority of a BRICS country has issued a decision on pure exploitative conduct by a digital platform similar to the decision of Bundeskartellamt on Facebook [Bundeskartellamt, 2019], where unfairness of contract terms with the final customer is sufficient condition for illegality.

From a value chain perspective, theories of harm applied to competition violations and to merger approval correspond can be "exploitative" in the sense that (1) restrictions of competition prevent upgrading of the participants along the same value chain, and (2) upgrading of the participants in the adjacent markets can be expropriated by the platform. The effect of expropriation (redistribution) of rent is articulated in the value chain perspective. If counterparties increase efficiency and reduce cost, the governing party decreases the compensation without passthrough to the final customers. One can use dominance at one or more stages of the vertical chain to expropriate the surplus of others in other stages and this reduces/eliminates these targeted firms' incentives to innovate [Farrell, Katz, 2000]. To our knowledge, no competition authority explicitly includes this theory of harm as central in its decision. In the decisions on [FAS Russia, 2015], the Russian compe-

15 On the alternative approaches to theory of harm in Google search cases see [Iacobucci, Ducci, 2019]. 
tition authority mentions potential losses of application developers that receive lower fees that they could when competition in the application stores market takes place.

Generally, if competition law and economics apply the value chain theory instead of the (mostly) neoclassical notion of market dominance, a relevant exploitative theory of harm would be either prevention of upgrading or unfair redistribution of rent [Davis, Kaplinsky, Morris, 2018].

"Vertical fairness" in this context means contract terms that do not prevent upgrading of the participants of adjacent markets by expropriation of rents that parties may obtain for superior productivity. Different theories acknowledge the possibility of the gains obtained by cost reduction of quality improving to be expropriated. The theory of incomplete contracts develops a framework of relationship-specific investments and appropriable quasi-rent [Klein, Crawford, Alchian, 1978 $]^{16}$. There is however an important obstacle to building the theory of harm using an incomplete contract framework. Hold-up theory predicts that a rational independent agent would not be willing to invest in relationship-specific assets under the threat of hold-up. In the incomplete contract theory, the underinvestment problem is resolved by vertical integration or FRAND commitments, and vertical integration resolves the problem of rent expropriation. In the context of dominant platform businesses, participants in adjacent markets might be locked into the contractual relationship so that their rents are appropriated by platforms. However, in a pure frame-

16 An interesting parallel between the theory of appropriable quasi-rent and definition of platform in strategic management is the notion of cooperative relation-specific investments [Che, Hausch, 1999]. Cooperative investments are those that, first, are relationship-specific, and, second, benefit the partner of the investor but not investor himself. This benefit is exactly the effect of the investments of the participants in a market adjacent to the platform if we distinguish between platform and aggregator. work of incomplete contracts, it would be difficult to explain how the lock-in emerges, if a rational counterparty does not invest or invests insufficiently under the threat of hold-up. Normative analysis shows the impact of potential hold up on the investment to upgrading but it would be extremely difficult to find positive evidence in favor of the hypothesis on the negative impact of potential hold up on competition.

Generally, discussing this issue is avoided in the modern literature on global value chains. Providing extensive evidence of financialization [Milberg, 2008a, 2008b; Milberg, Winkler, 2011], that is, appropriation of the cost reduction and quality improvement of the subordinated firms in the value chain by the lead one, authors do not provide an explanation of the efforts and investments of the first group.

This notion of exploitation differs from exclusionary theories of harm that competition enforcement applies even in very proregulatory regimes such as Russia. It is not yet a part of a notion of exploitative antitrust violations. The closest is low monopolistic price in Russian competition law, where low monopolistic price is the contract price paid by dominant buyer. There are no instances of the application of low monopolistic price towards MSPs. Similarly, decisions do not apply the notion of abuse of economic dependence [Bougette, Budzinski, Marty, 2018] ${ }^{17}$.

If we nevertheless would develop a theory of harm using some version of incomplete contract and/or global value chain framework, it seems to be necessary, first, to acknowledge the unequal bargaining power of the seemingly independent parties. The explanation of the incentives and instruments of abuse would then be directly borrowed from the global value chain concept. The lead firm is

17 For Russian competition law, the explanation of the absence of a specific notion of economic dependence is that the notion of market dominance in the practice of enforcement captures the idea of strong dependence. In some extreme cases, competition authorities define market boundaries as bilateral relationships [Avdasheva, 2016]. 
able to appropriate rents accumulated by subordinated parties until there is a better outside option. Recall that it is only the lead firm in contrast to a subordinated one that has outside options. Competing to be the better outside option that is the only one that is able to keep the rent, subordinated firms allow for the lead firm to appropriate the gains they create. In the neoclassic analogue of this framework, welfare losses are the losses of distributional efficiency due to increasing inequality in the economy.

If we start from this point, then the evidence of abuse would be a large passthrough of the investments of the participants in adjacent markets on the profits of the lead firm. Until now, no competition regimes, including interventionist ones, is ready to go that far. Even if we accept the point that the rent appropriation in particular circumstances is possible (in the world of incomplete contracts with imperfectly informed users of platforms), and the asymmetric pass-through is an indicator of exploitative abuse (in terms of competition economy), the issue of measurement and comparison of this pass-through is hardly resolved. A similar issue arises in the attempts to enforce against excessive pricing. In Europe, an excessive price includes the characteristics of "unfairness". However, four decades of enforcement have not allowed elaborating the proper threshold of "fairness". A pass-through of efficiency gains from investments is much more difficult to decide on. As for excessive pricing, there is no proper threshold for a "fair" distribution of gains. Additionally, in contrast to the excessive pricing, the pass-through of efficiency gains is not directly observable.

\subsection{Efficiencies and Multi-sided Markets}

Antitrust decisions towards MSP in BRICS rarely contain explicit assessments of efficiencies. One formal reason is that presumed violations of MSPs are more often illegal per se. For instance, tying of pre-installed ap- plications with restrictions of pre-installation of competing applications [FAS Russia, 2015] is illegal per se. Another limitation on efficiency analysis arises from the fact that national authorities, when analyzing welfare effects, concentrate only on domestic markets. Under the global presence of a digital MSP, efficiencies captured by a platform would be missing from the analysis.

Under antitrust enforcement, an exception is the analysis of Most-Favored Nation (MFN) clause as a device to prevent freeriding towards a platform by the hotels in the CADE investigation in Booking/Expedia/Decolar [CADE, 2018a]. CADE mentions that the threat of freeriding may destroy the positive welfare effects of a business model that minimizes transaction costs for the customers; therefore, efficiencies follow from the transaction-cost minimization.

In turn, there are examples of effect assessment, including efficiencies, in the decisions on mergers and ex-post evaluation of entry. An example of the latter is the assessment of UBER entry in Brazilian municipal markets during 2014-2016 [CADE, 2018b]. Ex-post analysis, which becomes important under discussions on proposed regulations of the taxi applications market, was concentrated on two main effects: price (fares) and entry conditions (measured by the quantity supplied by competitors). Therefore, the CADE approach addresses both final customers (passengers) and the effects on competitors. For the latter, CADE poses the question of whether a platform crowds out "traditional" transactions. Under the approval of the Yandex-Uber merger in Russia [FAS Russia, 2017a], FAS discussed similar evidence on decreases of fare per kilometer and changes in the number of rides by independent taxi services.

\subsection{Competition Remedies}

Remedies normally appear under merger approval. In some BRICS countries, especially Russia, remedies are also issued under infringement decisions and as a part of so-

PЖM 17 (4): 547-568 (2019) 
called warnings and precautions - specific procedures to suggest commitment to stop illegal conducts in exchange for the termination of investigation.

\subsubsection{Remedies promoting interplatform competition}

A typical remedy promoting interplatform competition is the support of the right of users to multi-home. This support was the most important remedy under the YandexUber merger in Russia [FAS Russia, 2017a]. Indian Competition Commission in 2012, in the Shopping case, ordered Google not to apply restrictive clauses in its negotiated direct search intermediation agreements with Indian partners. Remedies are aimed not only at naked restrictions on multihoming but also at indirect restrictions. An example is the commitment decision of Brazilian CADE in the Booking/Expedia/Decolar case [CADE, 2018a], where online travel agencies agreed to stop using a priceparity clause policy and renounce the conditions imposed on hotels that offer accommodations on their platforms.

Remedies for multi-homing tend to protect competition between MSPs, which is horizontal competition. Nevertheless, they may also affect vertical competition by limiting the unilateral bargaining power of particular digital platforms in their relationships with participants in adjacent markets. From a value chain perspective, the protection of multi-homing is very important, although not necessarily sufficient, to protect upgrading opportunities. In particular, in the investigation of Booking/Expedia/ Decolar, CADE specifically stresses the adverse effect of MFN clauses on the abilities of other agencies to enter the market and the distribution of rents between hotels and online travel agencies.

\subsubsection{Remedies promoting intraplatform competition}

In turn, remedies on fair access terms directly affect the bargaining position of platform users. They try to promote the ability of competing "unbundled" sellers in adjacent markets to supply their services using the capacities of the platform. Typically, this type of remedy addresses the issue of discrimination towards competing market participants by MSPs. In the simplest version, this type of remedy is presented by the settlement decision of Google with Russian FAS, in which Google voids the exclusionary clause of its Android applications and commits not to encourage original equipment manufacturers (OEMs hereafter) to install only Google applications [FAS Russia, 2017b]. Thus, competing sellers can take advantage of using Android OS under conditions that are typical to essential facilities that are subjects of specific access rules, being a bottleneck in the markets.

Remedies in the Google Search case in India address the ability of all noncaptive participants in adjacent markets to be presented in the search results in a search engine as a platform. The decision explicitly states: “... as Google has the ability and the incentive to abuse its dominant position, its "special responsibility" is critical in ensuring not only the fairness of the online web search and search advertising markets but also the fairness of all online markets, given that these are primarily accessed through search engines" [Competition Commission of India, 2012, p. 79]. Relevant remedial requirements should display a disclaimer on the commercial flight unit box that clearly states that the "search flights" link at the bottom leads to Google's Flights page rather than the results aggregated by any other third-party service provider, so that users are not misled.

Clauses that directly promote intraplatform competition also appear in decisions on mergers. Such decisions may address many adjacent markets, even without a specific analysis of competition concerns. For example, MOFCOM in Google-Motorola merger [MOFCOM, 2012] specifies rather general conditions for business practice in China:

- maintain free Android open source licensing for 5 years; 
- maintain nondiscriminatory access to its Android system for 5 years;

- continue licensing Motorola Mobility patents on a fair, reasonable and nondiscriminatory (FRAND) basis.

Generally, remedies addressing intraplatform contracts directly support vertical but not horizontal competition. They concentrate on the objective of preserving competition in adjacent rather than platform markets.

Being criticized for the extensive use of remedies, which are normally a part of regulation, not antitrust enforcement, Russian FAS sometimes succeeds to promote nondiscriminatory competition in a timely manner. A recent example is Microsoft's allegation of discrimination against competing developers of anti-malware software. This case concerned Microsoft's policies on the advance provision to competing software developers of so-called "release to manufacturing" (or RTM) versions of its Windows 10 OS. Timely access to RTM OS versions is required to allow competing developers to update their anti-malware products to ensure compatibility with a new OS before its release. Kaspersky Lab, one of the largest Russian anti-malware developers, submitted a complaint to the FAS, alleging that Microsoft provided the RTM version of Windows 10 to competing anti-malware developers only six days before the new OS was released. Moreover, Microsoft allegedly designed its Windows Defender security feature in a manner to induce users to favor Microsoft's own anti-malware products over those offered by competitors. The FAS found Microsoft's conduct to amount to an abuse of dominance by creating discriminatory conditions for rivals. The investigation did not result in an infringement decision, because after receiving a formal warning complemented by remedies, Microsoft decided to comply with the warning's requirements.

Until recently, the potential scope of remedies in Russia is limited by safe harbor on intellectual property rights (IPRs). After the proposed amendments of the law "On protection of competition" that would remove this safe harbor one may expect more remedies aimed to protect intra-platform competition, with a large capacity to influence potential strategies of digital platforms. Chinese competition law enforcement provides an important example of the remedies applied to Qualcomm that regulate the terms and conditions of IPR licensing [Allen, Overy, 2015].

\subsubsection{Remedies affecting competition outside competition law}

Regulatory interventions that affect competition in the markets do not necessarily use traditional tools of competition policy within competition legislation. Restrictions for foreign-originated platforms due to the specific requirements for the collection and use of data have an important stimulating effect on domestic competing platforms. The development of Baidu, AliBaba and Tencent in China was supported by specific requirements for data protection and data sharing. The China Operating System, if successful, will be another example of an alternative approach to competition development in BRICS.

There is no consistent assessment of the economic effects of the Chinese model of competition protection. Recently, however, in the Chinese markets adjacent to digital platforms (such as advertising, online video, music, $\mathrm{B} 2 \mathrm{C}$ and $\mathrm{O} 2 \mathrm{O}$ commerce, mobile payment and logistic, etc.), there is competition between the platforms that necessarily benefits participants of these adjacent markets.

In Russia, a draft of the law that should affect vertical competition between platforms and adjacent markets outside the scope of traditional competition enforcement was issued at the beginning of 2019. The proposed changes to the Russian law "On communications" require for all mobile devices imported into Russia, first, domestic applications (including antivirus, browser, messenger and geolocation) should be preinstalled; second, all pre-installed applications developed by foreign companies should

PЖM 17 (4): 547-568 (2019) 
be removable. The expected effect is the redistribution of rents created in the value chain of the digital platform towards domestic application developers. However, this type of requirements is much closer to competition remedies promoting intraplatform competition and a supporting model of independent development of domestic digital platforms.

\section{CONCLUSIONS AND IMPLICATIONS}

In the last decade, BRICS competition authorities have obtained records on competition enforcement towards MSPs. Under enforcement of competition legislation, theories of harm in investigations and decisions are mostly of an exclusionary, not exploitative nature. Discrimination and tying are typical qualifications of anticompetitive conduct. Exclusionary effects constitute competition concerns under merger approval. Until recently, few contained quantitative assessments of effects - but such assessments do not differentiate substantially between BRICS competition decisions and decisions in mature jurisdictions.

No restriction on multi-homing is a universal remedy under both investigations of infringements and merger notifications. Special attention to vertical restraints with exclusionary effects reflects post-Chicago law and economics concerns about incentives to restrict competition. In this respect, the approach of BRICS contradicts neither the economic theory of competition in platform markets nor the practice of developed countries. An important gap in the decisions is the efficiency defense; competition authorities rarely undertake this type of analysis. It seems that neither do companies under enforcement try to develop this line of defense. Decisions on MSPs in BRICS rarely use a specific economic theory of platform competition (if any do so at all). They mostly rely on the standard theory of competition.
The economic theory of platforms does not exclude exploitative theories of harm. However, BRICS competition authorities do not apply them. In this context, the approach to identify potentially illegal actions is not harsher than in EU competition authorities. Moreover, until recently, no competition authority applied competition legislation against exploitative abuses of dominance by MSPs in the manner that Bundeskakrtellamt does.

It does not necessarily mean that BRICS competition authorities do not intend to protect domestic participants of the markets adjacent to platforms. However, they consider protection of multi-homing as most efficient tools to prevent exploitations of business users. It seems unlikely that BRICS competition authorities in the nearest future will apply specific policies to protect private users, the same way as Bundeskartellamt in the decision on Facebook does.

At the same time, BRICS authorities apply broad standards of competition as a benchmark of legal conducts. In addition, recent competition enforcement towards MSPs shows that authorities successfully share their experience. Not only BRICS authorities adopt the approaches suggested in mature jurisdictions, but also vice versa.

BRICS competition enforcement may substantially influence the business models of platforms. In order to avoid competition enforcement, dominant platforms should avoid anticompetitive conducts, first of all, single-homing, unless it has pronounced reasons not related to anticompetitive intensions. In markets where competition between platforms takes place, rivals of platforms may obtain protection from business stealing due to unreasonable singlehoming requirements. In markets where competition takes place on the platform, it is more difficult to find a clear criterion to discriminate competition on the merits from exclusionary conducts in many circumstances. However, competition on platforms may also be protected by competition enforcement. 


\section{ACKNOWLEDGMENTS}

Authors cordially thank for the fruitful discussions and valuable comments Ioannis $\mathrm{Li}^{-}$ annos, Pierre Regibeau, Eduardo Pontual Ribeiro and the participants of 14th Annual Competition and Regulation Conference (CRESSE). All mistakes are ours.

\section{REFERENCES}

Aghion P., Bolton P. 1987. Contracts as a barrier to entry. The American Economic Review 77 (3): 388-401.

Akman P. 2018. A preliminary assessment of the European Commission's Google Android decision. Competition Policy International Antitrust Chronicle.

Amelio A., Karlinger L., Valletti T. 2018. Exclusionary practices and two-sided platforms. In: Rethinking Antitrust Tools for Multi-Sided Platforms; 131-147. OECD Publishing.

Amelio A., Buettner T., Hariton C., Koltay G., Papandropoulos P., Sapi G., Valletti T., Zenger H. 2018. Recent developments at DG competition: 2017/2018. Review of Industrial Organization 53 (4): 653-679.

Antitrust in China: "NDRC v. Qualcomm One All". 2015. Allen \& Overy. [Electronic resource]. https://www.allenovery.com/en$\mathrm{gb} / \mathrm{global} /$ news-and-insights/publications/ antitrust-in-china-ndrc-v--qualcomm--oneall (accessed: 05.08.2019).

Armstrong M. 2006. Competition in two-sided markets. RAND Journal of Economics 37 (3): 668-691.

Armstrong M., Wright J. 2007. Two-sided markets, competitive bottlenecks and exclusive contracts. Economic Theory 32 (2): 353-380.

Avdasheva S. 2016. Models of monopoly in the quarter-century development of Russian competition policy: Understanding competition analysis in the abuse of dominance investigations. In: F. Jenny, Y. Katsoulacos (eds). Competition Law Enforcement in the BRICS and in Developing Countries; 189-210. Springer: N.Y.

Bain J.S. 1956. Barriers to New Competition. Harvard University Press: Cambridge.

Baseman K. C., Warren-Boulton F. R., Woroch G.A. 1995. Microsoft plays hardball:

The use of exclusionary pricing and technical incompatibility to maintain monopoly power in markets for operating system software. The Antitrust Bulletin 40 (2): 265-315.

Baumol W.J. 1982. Contestable markets: An uprising in the theory of industry structure. American Economic Review 72 (1): $1-15$.

Becchetti L., Paganetto L. 2001. The determinants of suboptimal technological development in the system company-component producers relationship. International Journal of Industrial Organization 19 (9): 1407-1421.

Boudreau K. J., Hagiu A. 2009. Platform rules: Multi-sided platforms as regulators. In: A. Gawer (ed.). Platforms, Markets and Innovation. Edward Elgar Publishing: Cheltenham, UK.

Bougette P., Budzinski O., Marty F. 2018. Exploitative Abuse and Abuse of Economic Dependence: What Can We Learn From an Industrial Organization Approach? Working Paper. [Electronic resource]. https:// papers.ssrn.com/sol3/papers.cfm?abstract $\mathrm{id}=3086714$ (accessed: 15.12.2019).

Bundeskartellamt. 2019. Facebook, Exploitative Business Terms Pursuant to Section 19(1) Gwb for Inadequate Data Processing. [Electronic resource]. https:// www.bundeskartellamt.de/SharedDocs/ Entscheidung/EN/Fallberichte/Missbr auchsaufsicht/2019/B6-22-16.html;jses sionid=662562E324C7E6C197A1DCB688 6E072D.1_cid371?nn=3600108 (accessed: 01.08.2019).

CADE. 2013. Administrative Proceeding No.08700.005694/2013-19. [Electronic resource]. https://sei.cade.gov.br/sei/modulos/pesquisa/md_pesq_documento_consulta_externa.php?DZ2uWeaYicbuRZEFhBt- 
n3BfPLlu9u7akQAh8mpB9yPU6WEVpq sD71wZh_UXEHbWnGimCEVH_DWu20 Vj-yrkhN0rSaUY_vZle-vW6Lie0JKIptM DQRdZ40fQuKWEDXD2 (accessed: 01.08. 2019) (In Portuguese)

CADE. 2018a. CADE Booking, Decolar, and Expedia reach Cease and Desist Agreement with. [Electronic resource]. http://en.cade. gov.br/press-releases/booking-decolarand-expedia-reach-cease-and-desist-agreement-with-the-brazilian-administrativecouncil-for-economic-defense (accessed: 30.07.2019).

CADE. 2018b. CADE Analyzes the Competitive Effects of the Uber's Entry in the Market, Especially over Taxi Apps. [Electronic resource]. http://en.cade.gov.br/cade-analyzes-the-competitive-effects-of-the-uber 2019s-entry-in-the-market-especially-overtaxi-apps (accessed: 30.07.2019).

Calzolari G., Denicolò V. 2013. Competition with exclusive contracts and market-share discounts. American Economic Review 103 (6): $2384-2411$.

Che Y.-K., Hausch D.B. 1999. Cooperative investments and the value of contracting. American Economic Review 89 (1): 125147.

Competition Commission of India. 2012. Case No. 07 and 30 of 2012. [Electronic resource] https://www.cci.gov.in/sites/default/files/ 07\%20\&\%20\%2030\%20of\%202012.pdf (accessed: 01.08.2019).

Davis D., Kaplinsky R., Morris M. 2018. Rents, power and governance in global value chains. Journal of World-Systems Research 24 (1): 43-71.

Dixit A. 1980. The role of investment in entry-deterrence. The Economic Journal 90: 95-106.

Economides N. 2001. The Microsoft antitrust case. Journal of Industry, Competition and Trade 1 (1): 7-39.

Eisenmann Th., Parker G., Van Alstyne M. 2006. Strategies for two-sided markets. Harvard Business Review 84 (10): 92-101.

Eisenmann T., Parker G., Van Alstyne M. 2011. Platform envelopment. Strategic Management Journal 32 (12): 1270-1285.

European Commission. 2016. Big Data and Digital Platforms. [Electronic resource]. https://ec.europa.eu/growth/industry/policy/digital-transformation/big-data-digital-platforms_da (accessed: 10.09.2019).

European Commission. 2017a. Case AT.39740. Google Search (Shopping). [Electronic resource]. https://ec.europa.eu/competition/ elojade/isef/case_details.cfm?proc_code $=$ 1_39740 (accessed: 12.09.2019).

European Commission. 2017b. Commission Fines Google $€ 2.42$ Bln. for Abusing Dominance as Search Engine by Giving Illegal Advantage to Own Comparison Shopping Service. [Electronic resource]. http://europa.eu/rapid/press-release_IP-17-1784_en. htm (accessed: 01.08.2019).

European Commission. 2018. Antitrust: Commission Fines Google $€ 4.34$ Bln. for Illegal Practices Regarding Android Mobile Devices to Strengthen Dominance of Google's Search Engine. [Electronic resource]. https:// europa.eu/rapid/press-release_IP-18-4581_ en.htm (accessed: 01.08.2019).

European Commission. 2019. Antitrust: Commission Fines Google $€ 1.49 \mathrm{Bln}$. for Abusive Practices in Online Advertising. [Electronic resource]. https://europa.eu/rapid/ press-release_IP-19-1770_en.htm (accessed: 01.08.2019).

Evans D.S., Noel M.D. 2008. The analysis of mergers that involve multisided platform businesses. Journal of Competition Law and Economics 4 (3): 663-695.

Farrell J., Katz M.L. 2000. Innovation, rent extraction and integration in systems markets. Journal of Industrial Economics 48 (4): 413-432.

FAS Russia. 2015. Case No. AD/54066/15. [Electronic resource]. https://br.fas.gov. $\mathrm{ru} / \mathrm{ca} /$ upravlenie-regulirovaniya-svyazi-iinformatsionnyh-tehnologiy/ad-54066-15/ (accessed: 01.08.2019).

FAS Russia. 2017a. Case No. AG/82030/17. [Electronic resource]. https://br.fas.gov. $\mathrm{ru} / \mathrm{ca} /$ upravlenie-regulirovaniya-svyazi-iinformatsionnyh-tehnologiy/ag-82030-17/ (accessed: 01.08.2019). (In Russian)

FAS Russia. 2017b. FAS Russia Reaches Settlement with Google. [Electronic resource]. https://en.fas.gov.ru/press-center $/$ news/detail.html?id=49774 (accessed: 01.08.2019). 
FAS Russia. 2019. Analytical Report on the Competition in the Market of Services of Informational Intermediation between Taxi Drivers and Taxi Passengers (Market of Taxi Aggregators). [Electronic resource] https://fas.gov.ru/documents/ 678673 (accessed: 01.08.2019). (In Russian)

Gawer A. 2011. Platforms, Markets and Innovation. Edward Elgar Publishing: Cheltenham, UK.

Gawer A., Cusumano M. A. 2014. Industry platforms and ecosystem innovation. Journal of Product Innovation Management 31 (3): 417-433.

Gereffi G., Humphrey J., Sturgeon T. 2005. The governance of global value chains. $R e$ view of International Political Economy 12 (1): 78-104.

Giannaccari A., Van den Bergh R. 2017. Unilateral conduct of dominant firms. In R. Van den Bergh (ed.). Comparative Competition Law and Economics; 300-381. Edward Elgar Publishing: Cheltenham.

Gilbert R.J., Katz M.L. 2001. An economist's guide to US v. Microsoft. Journal of Economic Perspectives 15 (2): 25-44.

Graef I. 2016. EU Competition Law, Data Protection and Online Platforms: Data as Essential Facility. Walters Kluwer: Alphen aan den Rijn, Netherlands.

Graef I., Wahyuningtyas S. Y., Valcke P. 2015. Assessing data access issues in online platforms. Telecommunications Policy 39 (5): $375-387$.

The Guardian. 2019. Facebook to Be Fined $\$ 5$ bn for Cambridge Analytica Privacy Violations. [Electronic resource]. https:// www.theguardian.com/technology/2019/ jul/12/facebook-fine-ftc-privacy-violations (accessed: 10.09.2019).

Haucap J., Stühmeier T. 2015. Competition and Antitrust in Internet Markets. DICE Discussion Paper, No 199. Düsseldorf Institute for Competition Economics (DICE): Düsseldorf.

Heim M., Nikolic I. 2019. A FRAND regime for dominant digital platforms. Journal of Intellectual Property, Information Technology and E-Commerce Law 10 (1): 3855 .
Iacobucci E., Ducci F. 2019. The Google search case in Europe: Tying and the single monopoly profit theorem in two-sided markets. European Journal of Law and Economics 47 (1): 15-42.

Jacobides M., Sundararajan A., Van Alstyne M. 2019. Platforms and Ecosystems: Enabling the Digital Economy. Briefing paper. World Economic Forum.

Jenny F. 2018. Abuse of dominance by firms charging excessive or unfair prices: An assessment. In: Y. Katsoulacos, F. Jenny (eds). Excessive Pricing and Competition Law Enforcement; 5-70. Springer Nature Switzerland AG: Basel.

Karlinger L., Motta M. 2012. Exclusionary pricing when scale matters. The Journal of Industrial Economics 60 (1): 75-103.

Katsoulacos Y., Avdasheva S., Golovanova S. 2016. Legal standards and the role of economics in Competition Law enforcement. European Competition Journal 12 (2-3): 277-297.

Katsoulacos Y., Jenny F. 2018. Excessive Pricing and Competition Law Enforcement. Springer.

Katz M.L., Shapiro C. 1985. Network externalities, competition, and compatibility. American Economic Review 75 (3): 424440.

Katz M.L., Shelanski H.A. 2005. "Schumpeterian" competition and antitrust policy in high-tech markets. Competition 14: 47-67.

Kelly J. 2019. Justice department is investigating Google, Apple, Facebook and Amazon for monopolistic activities. Forbes. [Electronic resource]. https://www.forbes. com/sites/jackkelly/2019/07/24/justicedepartment-is-investigating-google-applefacebook-and-amazon-for-monopolistic-ac tivities/\#36066f93ba6b (accessed: 12.09. 2019).

Klein B., Crawford R. G., Alchian A. A. 1978. Vertical integration, appropriable rents, and the competitive contracting process. The Journal of Law and Economics 21 (2): 297-326.

Klein B. 2001. The Microsoft case: What can a dominant firm do to defend its market position? Journal of Economic Perspectives 15 (2): 45-62. 
Lee R.S. 2013. Vertical integration and exclusivity in platform and two-sided markets. American Economic Review 103 (7): 2960-3000.

Lévêque F. 2005. Innovation, leveraging and essential facilities: Interoperability licensing in the EU Microsoft case. World Competition 28 (1): 71-91.

Lianos I. 2017. Global Governance of Antitrust and the Need for a BRICS Joint Research Platform in Competition Law and Policy. In: E. Fox, T. Bonakele, L. McNube (eds). Competition Policy for the New Era: Insights from the BRICS Countries. Oxford University Press.

Milberg W. 2008a. Shifting sources and uses of profits: Sustaining US financialization with global value chains. Economy and Society 37 (3): 420-451.

Milberg W. 2008b. Outsourcing economics. In: D. Ruccio (ed.). Economic Representations; 72-88. Routledge.

Milberg W., Winkler D. 2011. Economic and social upgrading in global production networks: Problems of theory and measurement. International Labour Review $\mathbf{1 5 0}$ (3-4): 341-365.

MOFCOM Conditional Clearance of GoogleMotorola Mobility Acquisition. 2012. Zhong Lun Law Firm. [Electronic resource]. http://www.zhonglun.com/UpFile/File/201206121014294533.pdf (accessed: 30.07.2019).

Muzellec L., Ronteau S., Lambkin M. 2015. Two-sided Internet platforms: A business model lifecycle perspective. Industrial Marketing Management 45: 139-150.

Rasmusen E.B., Ramseyer J.M., Wiley J.S. 1991. Naked exclusion. The American Economic Review 81 (5): 1137-1145.

Rochet J.-C., Tirole J. 2006. Two-sided markets: A progress report. The RAND Journal of Economics 37 (3): 645-667.

Schmalensee R. 1981. Monopolistic two-part pricing arrangements. Bell Journal of Economics 12 (2): 445-466.
Spence A. M. 1977. Entry, capacity, investment and oligopolistic pricing. The Bell Journal of Economics 8 (2): 534-544.

Statista. 2019a. Market Value of the Top-10 Largest Companies in the World Worldwide as of August 2019 (in Bln. U.S. Dollars). [Electronic resource]. https://www. statista.com/statistics/263264/top-companies-in-the-world-by-market-value/ (accessed: 10.09.2019).

Statista. 2019b. Google's Revenue Worldwide From 2002 to 2018 (In Billion U.S. Dollars). [Electronic resource]. https://www. statista.com/statistics/266206/googles-annual-global-revenue/ (accessed: 12.09.2019).

Sylos-Labini P. 1957. Oligopoly and Technical Progress. English trans. by E. Henderson. 1962. Cambridge, MA: Harvard University Press.

Takigawa T. 2018. Super Platforms, Big Data, and the Competition Law: The Japanese Approach in Contrast with the US and the $E U$. ASCOLA Conference, New York University, 21-23 June 2018.

Tucker C. 2019. Digital data, platforms and the usual [antitrust] suspects: Network effects, switching costs, essential facility. Review of Industrial Organization 54 (4): 683-694.

Van Alstyne M.W., Parker G.G., Choudary S.P. 2016. Pipelines, Platforms, and the New Rules of Strategy. Harvard Business Review 94 (4): 54-62.

Walles Ch. 2018. The rise of platform business-how digital networks are changing competition. Dassault Systemes. [Electronic resource]. http://www.apriso.com/blog/ 2018/08/the-rise-of-platform-businesshow-digital-networks-are-changing-competition/ (accessed: 12.09.2019).

Whinston M. D. 1990. Tying, foreclosure, and exclusion. American Economic Review $\mathbf{8 0}$ (4): 837-859.

Whinston M.D. 2001. Exclusivity and tying in US v. Microsoft: What we know, and don't know. Journal of Economic Perspectives 15 (2): 63-80.

Initial Submission: September 30, 2019

Final Version Accepted: December 10, 2019 


\section{Сдерживает ли антилонопольная политика конкурентные стратегии цифровьх платфорл: практика БРИКС}

\section{С. Б. Авдашева}

Факультет экономических наук Национального исследовательского университета «Высшая школа экономики», Россия

\section{Д. В. Корнеева}

Факультет экономики Национального исследовательского университета «Высшая школа экономики» в Нижнем Новгороде, Россия

Конкурентные стратегии платформ часто включают в себя систему контрактов, которые могут рассматриваться в качестве антиконкурентных. В результате решений Европейской комиссии в отношении Google (2017 и 2018 гг.) и Федерального антимонопольного ведомства Германии (Bundeskartellamt) в отношении Facebook (2019 г.) стандарты ответственности за злоупотребления, применяемые антимонопольными органами, будут влиять на бизнес-модели цифровых платформ. В статье рассмотрены объяснения антиконкурентных эффектов, накладываемые органами конкурентной политики БРИКС применительно к многосторонним платформам. Предполагается, что подход БРИКС является более жестким по сравнению со зрелыми юрисдикциями (в первую очередь Европейским союзом). Однако проведенный анализ свидетельствует о том, что в центре внимания антимонопольных расследований БРИКС были те же самые вопросы дискриминации и связанных продаж с исключающими эффектами. При этом предписания в рассмотренных решениях о нарушении антимонопольного законодательства призваны защитить конкуренцию путем обязательств неисключительного использования платформ (multi-homing). Также нельзя утверждать, что антимонопольные органы БРИКС применяют какую-то особую экономическую теорию многосторонних платформ. Исключительная важность представленных выводов объясняется тем, что в силу размера целевых рынков антимонопольные органы БРИКС могут препятствовать практике вытеснения платформами друг друга с мирового рынка.

Ключевые слова: многосторонняя платформа, конкурентная политика, правоприменение, объяснения антиконкурентных эффектов, БРИКС.

$J E L:$ L40, L41, L42, K21, L14.

For citation: Avdasheva S.B., Korneeva V.D. 2019. Does competition enforcement prevent competitive strategies of digital platforms: Evidence from BRICS. Russian Management Journal 17 (4): $547-568$.

Статья поступила в редакиию 30 сентября 2019 г. Принята к публикации 10 декабря 2019 г. 